\title{
Biocontrol of Postharvest Diseases of Jujube Fruit by Cryptococcus laurentii Combined with a Low Dosage of Fungicides Under Different Storage Conditions
}

\author{
Guo Zheng Qin and Shi Ping Tian, Key Laboratory of Photosynthesis and Environmental Molecular Physiology, \\ Institute of Botany, Chinese Academy of Sciences, Xiangshan Nanxincun 20, Haidian District, Beijing 100093, \\ China
}

\begin{abstract}
Qin, G. Z., and Tian, S. P. 2004. Biocontrol of postharvest diseases of jujube fruit by Cryptococcus laurentii combined with a low dosage of fungicides under different storage conditions. Plant Dis. 88:497-501.

An antagonistic yeast, Cryptococcus laurentii, alone or in combination with a low dose of imazalil $(25 \mu \mathrm{g}$ a.i./ml $)$ or kresoxim-methyl $(50 \mu \mathrm{g}$ a.i./ml $)$, was investigated for its ability to control Alternaria alternata and Monilinia fructicola on jujube fruit under different storage conditions. Biocontrol activity of $C$. laurentii against $A$. alternata and $M$. fructicola at $20^{\circ} \mathrm{C}$ was enhanced significantly by combination with either fungicide. An integrated strategy for control of A. alternata and M. fructicola was developed that included a combination of C. laurentii, a low dose of fungicide, and controlled-atmosphere (CA) storage. Fruit treated with $C$. laurentii plus imazalil at $25 \mu \mathrm{g}$ a.i./ml or kresoxim-methyl at $50 \mu \mathrm{g}$ a.i./ml and stored in CA storage with $10 \% \mathrm{O}_{2}+0 \%$ $\mathrm{CO}_{2}$ at $0^{\circ} \mathrm{C}$ showed a lower disease incidence caused by both pathogens than fruit stored in air at $0^{\circ} \mathrm{C}$. Application of imazalil $(25 \mu \mathrm{g}$ a.i. $/ \mathrm{ml})$ or kresoxim-methyl $(50 \mu \mathrm{g}$ a.i. $/ \mathrm{ml})$ did not inhibit the growth of $C$. laurentii in wounds of jujube fruit stored in air at 20 and $0^{\circ} \mathrm{C}$ or in $\mathrm{CA}$ at $0^{\circ} \mathrm{C}$. The yeast grew rapidly in the wounds of jujube fruit under all storage conditions. The ability of C. laurentii to effectively control postharvest diseases of jujube fruit, the resistance of $C$. laurentii to low rates of fungicides, and the adaptability of this yeast to CA storage indicate that $C$. laurentii has great commercial potential as a biological control product.
\end{abstract}

Additional keywords: mode of action

Jujube (Zizyphus jujuba cv. Dongzao) fruit is susceptible to postharvest diseases caused by various pathogenic fungi. Alternaria alternata (Fr.:Fr.) Keissl. is the most important pathogen and causes latent infections and serious postharvest losses (28). Jujube fruit also can be infected by Monilinia fructicola (G. Wint.) Honey, Penicillium expansum Link, and Rhizopus stolonifer (Ehrenb.:Fr.) Vuill. through wounds that occur during harvest or packing (28). These decays are significantly reduced when fruit are stored in a controlled atmosphere (CA) at $-1{ }^{\circ} \mathrm{C}(28)$.

Synthetic chemical fungicides are the primary means to control postharvest diseases of jujube fruit (29), but concerns about public health, the environment, and the development of resistant pathogens have increased the search for alternative methods (33). Biological control using

Corresponding author: Shi Ping Tian

E-mail: tsp@ns.ibcas.ac.cn

This study was supported by the National Science Fund for Distinguished Young Scholars of China (30225030) and the National Natural Science Foundation of China (30170663).

Accepted for publication 21 December 2003.

Publication no. D-2004-0309-01R

(c) 2004 The American Phytopathological Society microbial antagonists is proving to be a reliable method of natural control of many postharvest pathogens $(6,9,16,19)$. Several antagonistic microorganisms have been found to effectively inhibit postharvest diseases $(9,11,16,23)$. At least four products are commercially available for postharvest disease control: Aspire, based on Candida oleophila (Ecogen Inc., Langhorn, PA), YieldPlus, base on Cryptococcus albidus (Anchor Yeast, Cape Town, South Africa), and Bio-Save 110 and BioSave 111, based on the bacterium Pseudomonas syringae (EcoScience, Orlando, FL) (7). Antagonists alone do not always provide commercially acceptable control of fruit decays, but their activity can be enhanced by manipulation of the environment, using mixtures of beneficial organisms, physiological and genetic enhancement of the biocontrol mechanisms, and integration of biocontrol with other methods, such as low doses of fungicides and CA storage $(2,12,25,26,30)$.

CA storage has been demonstrated to have fungistatic properties $(4,22)$. In our previous study, combining CA storage with biocontrol agents resulted in better control of postharvest diseases on apple and pear than CA storage or the biocontrol agents alone (30). To our knowledge, there is little information on the efficacy of combinations of antagonists with fungicides against postharvest pathogens in CA storage.
The objective of this study was to evaluate the effectiveness of Cryptococcus laurentii (Kuff.) C. E. Skinner, alone and together with a low dose of fungicide, for control of A. alternata and M. fructicola of jujube fruit. Disease control was determined in fruit stored in air at 20 and $0^{\circ} \mathrm{C}$, and in CA storage with $10 \% \mathrm{O}_{2}+0 \% \mathrm{CO}_{2}$ at $0^{\circ} \mathrm{C}$. In addition, the effect of fungicides on growth of $C$. laurentii in wounds of jujube fruit under various storage conditions was determined.

\section{MATERIALS AND METHODS}

Antagonists. $C$. laurentii was isolated from apple fruit following the method of Wilson and Chalutz (32). C. laurentii (IMI number 386832) was identified by the CABI Bioscience Identification Services (International Mycological Institute, Egham, UK). Yeast cells were cultured in nutrient-yeast-dextrose broth (NYDB: $8 \mathrm{~g}$ of nutrient broth, $5 \mathrm{~g}$ of yeast extract, and $10 \mathrm{~g}$ of dextrose in $1,000 \mathrm{ml}$ of water) for $48 \mathrm{~h}$ at $25^{\circ} \mathrm{C}$. Washed cell suspensions of the yeast were obtained by centrifugation at $6,000 \mathrm{rpm}(2,500 \times g)$ for $10 \mathrm{~min}$, resuspended in sterile distilled water, and centrifuged again. The concentration of the yeast was determined with a hemacytometer and adjusted to $1 \times 10^{8} \mathrm{CFU} / \mathrm{ml}$.

Pathogen. A. alternata and $M$. fructicola were isolated from infected jujube fruit and maintained on potato dextrose agar (PDA) for 14 days at $20^{\circ} \mathrm{C}$. The spores of both pathogens were suspended in $5 \mathrm{ml}$ of sterile distilled water containing $0.05 \%$ (vol $/ \mathrm{vol}$ ) Tween 80 , and filtered through four layers of sterile cheesecloth to remove any adhering mycelia. Spore concentrations of both A. alternata and $M$. fructicola were determined with a hemacytometer and adjusted to $1 \times 10^{5}$ spores $/ \mathrm{ml}$ with sterile distilled water.

Fruit materials. Jujube fruit were harvested at commercial maturity and sorted based on size and the absence of physical injuries or infections. The firmness of jujube fruit was $55.7 \mathrm{~N}$ as determined by a penetrometer (FT-327; UC Fruit Firmness Tester, Milano, Italy), and total soluble solids were $23.6 \%$. Fruit were disinfested with $2 \%$ (vol/vol) sodium hypochlorite for 2 min, washed with tap water, air dried prior to use within 2 days, and held at $0^{\circ} \mathrm{C}$ before use.

Biocontrol assays of yeasts under different storage conditions. Imazalil (Dec- 
cozil 25 EC; Elf Atochem North America, Inc., Philadelphia) and kresoxim-methyl (Stroby 50\% DF; BASF Ltd., Ludwigshafen, Germany) were used in this study. Jujube fruit were wounded (3 $\mathrm{mm}$ deep and $3 \mathrm{~mm}$ wide) with a sterile nail and treated with $25 \mu \mathrm{l}$ of the treatment suspensions as follows: $C$. laurentii $\left(10^{8}\right.$ $\mathrm{CFU} / \mathrm{ml}), C$. laurentii $\left(10^{8} \mathrm{CFU} / \mathrm{ml}\right)+$ imazalil $(25 \mu \mathrm{g}$ a.i./ml $)$, C. laurentii $\left(10^{8}\right.$ $\mathrm{CFU} / \mathrm{ml})+$ kresoxim-methyl $(50 \mu \mathrm{g}$ a.i./ml), imazalil (25 $\mu \mathrm{g}$ a.i./ml), kresoximmethyl $(50 \mu \mathrm{g}$ a.i./ml $)$, and sterile distilled water controls. After $4 \mathrm{~h}$, fruit were challenge inoculated with $20 \mu \mathrm{l}$ of the conidial suspensions of $A$. alternata or $M$. fructicola at $1 \times 10^{5}$ spores $/ \mathrm{ml}$. Treated fruit were placed in plastic boxes ( 250 by 150 by $50 \mathrm{~mm}$ ) with high humidity (about $95 \%$ ) and stored in air at 20 or $0^{\circ} \mathrm{C}$, or in CA storage with $10 \% \mathrm{O}_{2}+0 \% \mathrm{CO}_{2}$ at $0^{\circ} \mathrm{C}$. Jujube fruit are sensitive to high $\mathrm{CO}_{2}$ concentrations and, in a preliminary study, we found that CA with $10 \% \mathrm{O}_{2}+0 \% \mathrm{CO}_{2}$ at $0^{\circ} \mathrm{C}$ was effective to reduce postharvest decays (data not shown). Disease incidence and lesion diameter were measured after 5 days at $20^{\circ} \mathrm{C}$. Fruit stored at $0^{\circ} \mathrm{C}$ in air and in CA storage were observed after 40, 50, and 60 days. Each treatment was replicated three times with 15 fruit per replicate and the entire experiment was repeated twice.

Population dynamics of biocontrol yeasts under different storage conditions. Jujube fruit were wounded and treated with $25 \mu \mathrm{l}$ of the yeast suspension at $1 \times 10^{7} \mathrm{CFU} / \mathrm{ml}$, alone or in combina- tion with imazalil at $25 \mu \mathrm{g}$ a.i./ml or kresoxim-methyl at $50 \mu \mathrm{g}$ a.i./ml. Fruit were stored in air at 20 or $0^{\circ} \mathrm{C}$, or in CA storage with $10 \% \mathrm{O}_{2}+0 \% \mathrm{CO}_{2}$ at $0^{\circ} \mathrm{C}$, as described above. Fruit samples were taken as described by Janisiewiz et al. (13) at different times after treatment by removing the wound tissue with a cork borer. The resulting cylinders $(10 \mathrm{~mm}$ deep and 10 $\mathrm{mm}$ wide) of five jujube fruit were placed in a mortar with $10 \mathrm{ml}$ of sterile distilled water and ground with a pestle. Then, 50 $\mu \mathrm{l}$ of serial 10 -fold dilutions were plated on NYDA medium. Colonies of $C$. laurentii were counted after incubation at $20^{\circ} \mathrm{C}$ for $72 \mathrm{~h}$ and expressed as $\log _{10}$ $\mathrm{CFU} /$ wound. Each treatment was replicated three times, and the entire experiment was repeated three times.

Statistical analysis of data. Statistical analyses of the data were performed with Statistical Analysis System (version 6.12; SAS Institute, Cary, NC). Disease incidence, lesion diameter, and yeast population density were analyzed by two-way factorial analysis. Mean separations were performed by Student-Newman-Keuls test. To test whether the treatments produced similar results in each of the experimental repeats, the experimental repeats were included as a factor in the analysis of variance and the interaction between experimental repeat and treatment was tested for significance. A nonsignificant interaction was found in all cases between experimental repeat and treatment, indicating that treatment effects were similar among the experimental repeats. Results
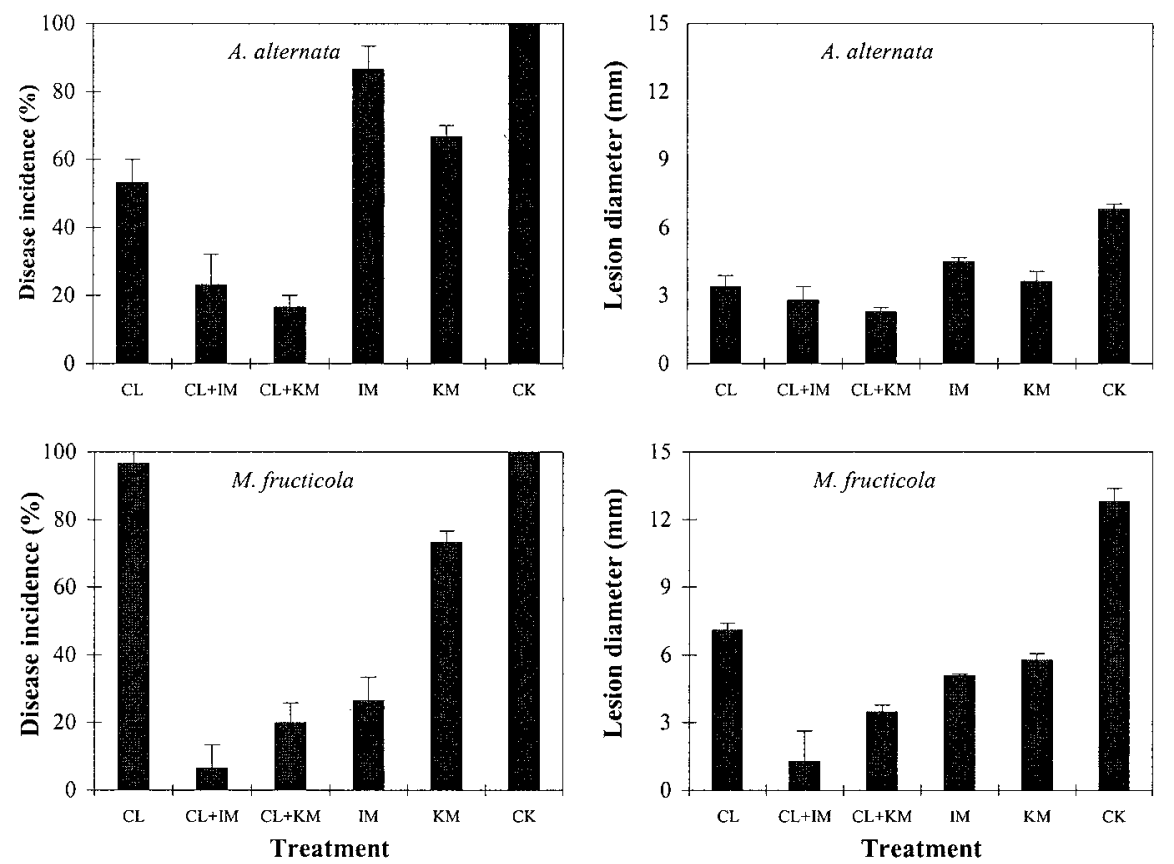

Fig. 1. Biocontrol efficacy of Cryptococcus laurentii (CL), alone or in combination with a low dose of imazalil (IM) or kresoxim-methyl (KM) fungicide, on decay of jujube fruit caused by Alternaria alternata and Monilinia fructicola at $20^{\circ} \mathrm{C}$. Fruit were wounded and treated with CL, CL+IM, $\mathrm{CL}+\mathrm{KM}, \mathrm{IM}, \mathrm{KM}$, or water (CK) and inoculated with A. alternata or M. fructicola. The data were based on three replicates of 15 fruit each and the test was repeated twice with similar results. Bars represent standard errors of the treatment means of pooled data. presented were pooled across repeated experiments.

\section{RESULTS}

Effect of combination of $C$. laurentii with fungicides at $20^{\circ} \mathrm{C}$ in air. The results from two experiments demonstrated that the antagonistic yeast $C$. laurentii, as well as low dosages of imazalil $(25 \mu \mathrm{g}$ a.i. $/ \mathrm{ml})$ and kresoxim-methyl $(50 \mu \mathrm{g}$ a.i./ml), were effective against $A$. alternata and $M$. fructicola in jujube fruit at $20^{\circ} \mathrm{C}$ (Fig. 1). Neither the yeast nor the two fungicide treatments caused any surface injury to the fruit. Better control of both pathogens was achieved by combining $C$. laurentii with each fungicide at a low dosage than with yeast or fungicide alone. After incubation for 5 days at $20^{\circ} \mathrm{C}$, fruit treated with $C$. laurentii plus imazalil $(25 \mu \mathrm{g}$ a.i./ml $)$ and inoculated with $A$. alternata or $M$. fructicola showed 77 and $93 \%$ less decay, respectively, than the controls. For both pathogens, lesion diameters also were significantly reduced by $C$. laurentii + imazalil. Similar results for control of $A$. alternata and $M$. fructicola were found in fruit treated with $C$. laurentii + kresoximmethyl $(50 \mu \mathrm{g}$ a.i. $/ \mathrm{ml})$ and stored at $20^{\circ} \mathrm{C}$.

Effect of combination of $C$. laurentii with fungicides at $0^{\circ} \mathrm{C}$ in air and $\mathrm{CA}$ storage. $C$. laurentii, alone or in combination with the fungicides imazalil $(25 \mu \mathrm{g}$ a.i./ml) or kresoxim-methyl (50 $\mu \mathrm{g}$ a.i./ml), controlled A. alternata and M. fructicola effectively at $0^{\circ} \mathrm{C}$ in air and in CA storage (Figs. 2 and 3). Complete control of $A$. alternata was obtained in fruit treated with C. laurentii + kresoxim-methyl at $0^{\circ} \mathrm{C}$ in air and in CA storage at 40, 50, or 60 days. The addition of imazalil to $C$. laurentii also enhanced the efficacy of the yeast against $A$. alternata, but the effect was greater when fruit were stored in CA storage than in air at $0^{\circ} \mathrm{C}$ for the same length of time (Fig. 2). Different results were observed for $M$. fructicola when fruit were treated with the yeast-fungicide combination. Complete control of $M$. fructicola was achieved by combining $C$. laurentii with imazalil at $0^{\circ} \mathrm{C}$ under CA storage. Combining $C$. laurentii with kresoxim-methyl enhanced the activity of the yeast against M. fructicola. Incidence of disease caused by $M$. fructicola was lower and lesion diameter was smaller in fruit treated with C. laurentii + kresoxim-methyl and kept in CA storage than in fruit stored at $0^{\circ} \mathrm{C}$ in air for the same period of time (Fig. 3). Incidence of decay increased and lesions enlarged as storage time increased, but the relative activity of the various treatments was consistent at 40,50, or 60 days. There was no significant difference in the data obtained in repeated experiments.

Influence of fungicides on the growth of $C$. laurentii under different storage conditions. The similar results obtained in repeated experiments indicated that population dynamics of $C$. laurentii in the 
wounds of jujube fruit were not significantly influenced by the application of imazalil $(25 \mu \mathrm{g}$ a.i./ml $)$ or kresoxim-methyl $(50 \mu \mathrm{g}$ a.i. $/ \mathrm{ml})$ in air at 20 or $0^{\circ} \mathrm{C}$, or in $\mathrm{CA}$ storage throughout the experiment (Fig. 4).
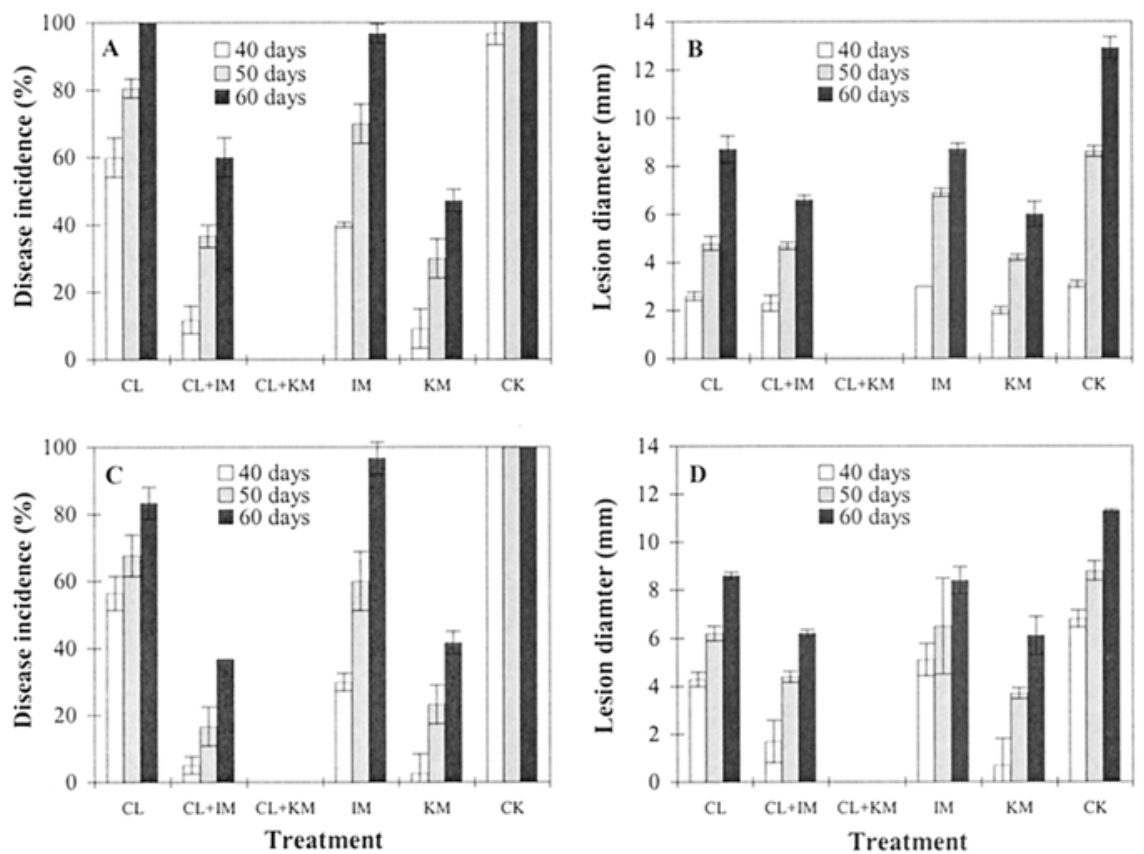

Fig. 2. Biocontrol efficacy of Cryptococcus laurentii (CL), alone or in combination with a low dose of imazalil (IM) or kresoxim-methyl (KM) fungicide, on decay of jujube fruit caused by Alternaria alternata at $0^{\circ} \mathbf{C ~} \mathbf{A}$ and $\mathbf{B}$, in air and $\mathbf{C}$ and $\mathbf{D}$, in controlled-atmosphere storage. Fruit were wounded and treated with CL, CL+IM, CL+KM, IM, KM, or water (CK) and inoculated with A. alternata and stored for 40,50 , or 60 days. The data were based on three replicates of 15 fruit each and the test was repeated twice with similar results. Bars represent standard errors of the treatment means of pooled data.
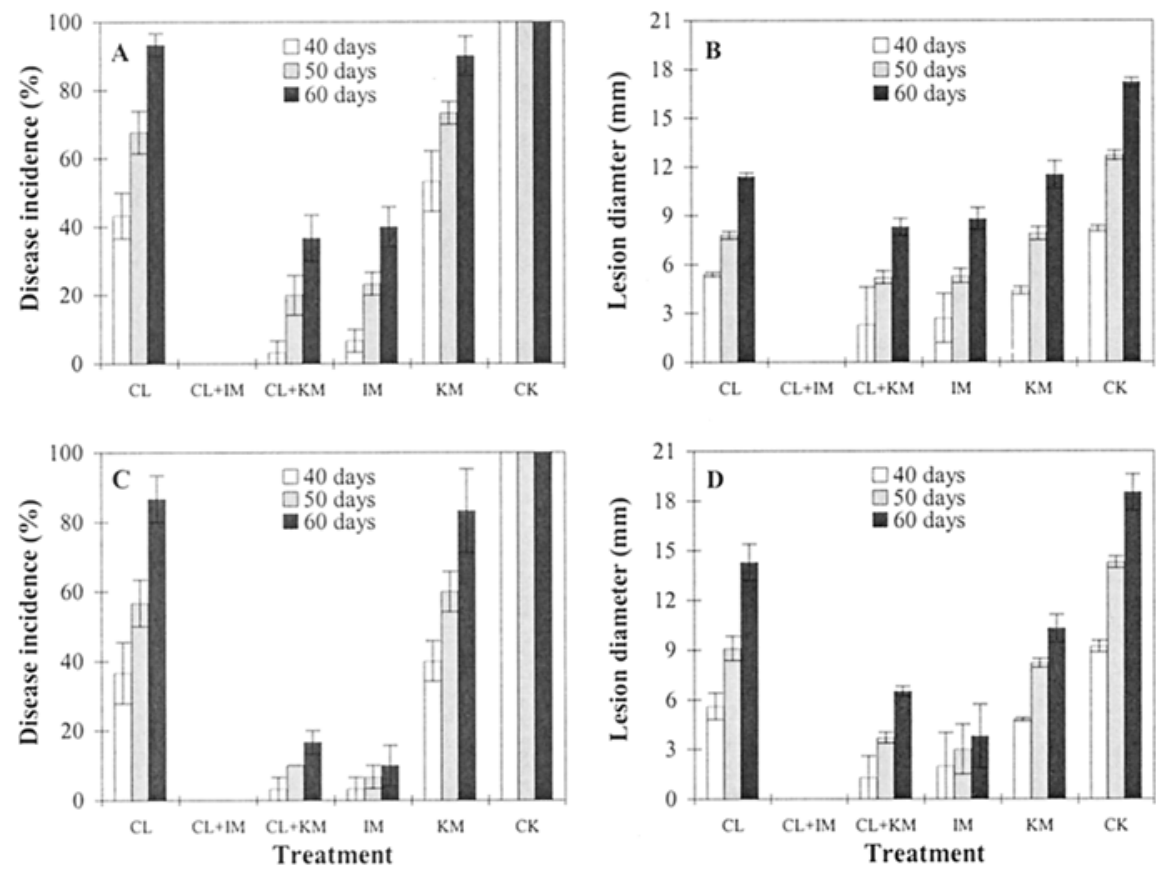

Fig. 3. Biocontrol efficacy of Cryptococcus laurentii (CL), alone or in combination with a low dose of imazalil (IM) or kresoxim-methyl (KM) fungicide, on decay of jujube fruit caused by Monilinia fructicola at $0^{\circ} \mathbf{C} \mathbf{A}$ and $\mathbf{B}$, in air and $\mathbf{C}$ and $\mathbf{D}$, in CA storage. Fruit were wounded and treated with CL, CL+IM, CL+KM, IM, KM, or water (CK) and inoculated with M. fructicola and stored for 40, 50, or 60 days. The data were based on three replicates of 15 fruit each and the test was repeated twice with similar results. Bars represent standard errors of the treatment means of pooled data.
(Fig. 4A). Low temperature and CA storage did not significantly affect the growth of $C$. laurentii. Populations of $C$. laurentii increased to almost the same levels in fruit treated with $C$. laurentii, $C$. laurentii + imazalil, and $C$. laurentii + kresoximmethyl after 56 days of incubation at $0^{\circ} \mathrm{C}$ in air or in CA storage (Figs. $4 \mathrm{~B}$ and $\mathrm{C}$ ).

\section{DISCUSSION}

C. laurentii in combination with a low dose of imazalil or kresoxim-methyl resulted in better control of both A. alternata and $M$. fructicola on jujube fruit than the yeast or the fungicide treatments alone at $20^{\circ} \mathrm{C}$ (Fig. 1). Combining fungicides with biocontrol agents proved to be an effective method to improve control of postharvest pathogens while reducing the chemical residues on the fruit in other studies $(2,10,25,27)$. Imazalil commonly is used for postharvest treatment of jujube fruit in China, and kresoxim-methyl is a new fungicide from the strobilurin group of chemicals (18). The general concentration of
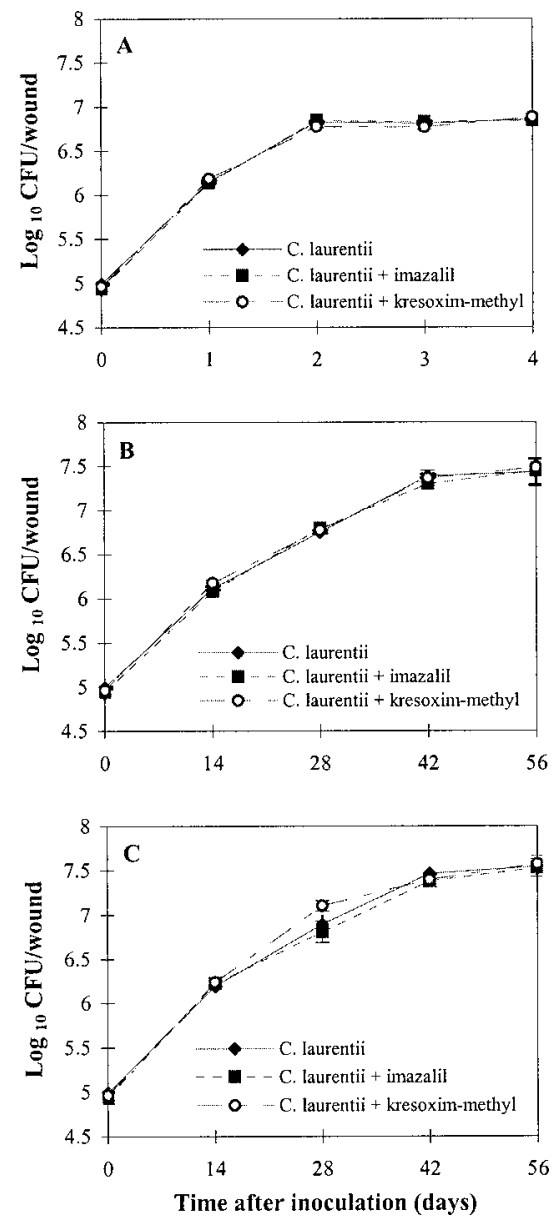

Fig. 4. Influence of imazalil and kresoximmethyl on population dynamics of Cryptococcus laurentii in wounds of jujube fruit in air at A, $20^{\circ} \mathrm{C}$ or $\mathbf{B}, 0^{\circ} \mathrm{C}$, or $\mathbf{C}$, in controlled-atmosphere storage at $0^{\circ} \mathrm{C}$. The data were based on three replicates and the test was repeated three times with similar results. Bars represent standard errors of the treatment means of pooled data. 
both fungicides necessary to significantly control postharvest diseases of jujube fruit is more than $300 \mu \mathrm{g}$ a.i./ml when used alone (data not shown).

CA storage at low temperatures is effective for control of various pathological and physiological problems that occur in stored fruit and vegetables $(14,20,31)$. Decay development is retarded because growth, sporulation, and enzyme activity of the pathogen are reduced, and the improved physiological condition of the host enables it to resist decay more effectively (21). However, as the fruit is removed from storage and placed at ambient temperature, decay develops rapidly and renders fruit commercially unacceptable (4). Consequently, CA storage cannot be used as a sole method for decay control. To optimize the benefit of CA, other methods, such as application of biological control agents or a reduced level of fungicides, are needed to completely prevent decay development and extend the shelf life of fruit $(3,24,30)$. In this experiment, we evaluated an integrated control strategy against $A$. alternata and M. fructicola decay of jujube fruit with a combination of a yeast, $C$. laurentii, a low dose of fungicide, and CA storage. Significantly better control of both pathogens was obtained when jujube fruit was treated with $C$. laurentii plus a low dose of imazalil or kresoxim-methyl and stored in CA storage than fruit treated with yeast or fungicide alone. Our previous work showed that $C$. laurentii combined with $\mathrm{CA}$ at $10 \% \mathrm{O}_{2}+10 \% \mathrm{CO}_{2}$ provided better control of A. alternata on sweet cherry fruit than the individual treatments alone (unpublished data).

The mode of action of antagonistic yeasts is complex. It may be due to competition for space and nutrients $(5,17)$, direct physical interaction with fungal hyphae, production of cell-wall lytic enzymes $(8,34)$, and induction of host resistance $(1,7)$. The effects of biological control of postharvest decay are likely the result of interactions of different factors. However, competition for nutrients and the ability to multiply rapidly in wounds of fruit may be the primary mechanisms by which $C$. laurentii exerts biocontrol activity (19). Thus, it is important that the colonizing ability of $C$. laurentii is not inhibited by fungicide. Lima et al. (15) reported that $C$. laurentii was not very sensitive to several fungicides commonly applied on fruit and vegetables. The result of our experiment showed that application of either imazalil or kresoxim-methyl at a low dosage did not significantly reduce the population of C. laurentii in the wounds of jujube fruit. C. laurentii multiplied quickly in fruit wounds in air at 20 and $0^{\circ} \mathrm{C}$, and in CA storage at $0^{\circ} \mathrm{C}$. It is quite possible that $C$. laurentii rapidly colonized the wound site of jujube fruit, effectively competed with the pathogens for nutrients, and resulted in starvation of the pathogens. Under these conditions, the pathogens may have been more sensitive to the fungicides, and the biocontrol efficacy of $C$. laurentii was enhanced.

Commercial development of $C$. laurentii as a biocontrol agent to control postharvest diseases of fruit is in progress (3). It is likely that the successful commercial use of biocontrol will depend on the compatibility of antagonists with postharvest practices, such as fungicide, low-temperature, and CA storage (30). The results reported here showed that $C$. laurentii was resistant to low rates of fungicides and was adapted to CA storage. The yeast grew rapidly in the wounds of jujube fruit under all storage conditions, including $\mathrm{CA}$ storage at $0^{\circ} \mathrm{C}$, regardless of whether the fungicides were used or not. This indicates that $C$. laurentii has great commercial potential as a biological control product.

\section{LITERATURE CITED}

1. Arras G. 1996. Mode of action of an isolate of Candida famata in biological control of Penicillium digitatum in orange fruits. Postharvest Biol. Technol. 8:191-198.

2. Chand-Goyal, T., and Spotts, R. A. 1996. Control of postharvest pear diseases using natural saprophytic yeast colonists and their combination with a low dosage of thiabendazole. Postharvest Biol. Technol. 7:51-64.

3. Chand-Goyal, T., and Spotts, R. A. 1997. Biological control of postharvest diseases of apple and pear under semi-commercial and commercial conditions using three saprophytic yeasts. Biol. Control 10:199-206.

4. De Vries-Paterson, R. M., Jones, A. L., and Cameron, A. C. 1991. Fungistatic effects of carbon dioxide in a package environment on the decay of Michigan sweet cherries by Monilinia fructicola. Plant Dis. 75:943-946.

5. Droby, S., Chalutz, E., Wilson, C. L., and Wisniewski, M. 1989. Characterization of the biocontrol activity of Debaryomyces hansenii in the control of Penicillium digitatum of grapefruit. Can. J. Microbiol. 35:794-800.

6. Droby, S., Cohen, L., Daus, A., Weiss, B., Horev, B., Chalutz, E., Kate, H., Keren-Tzur, M., and Shachnai, A. 1998. Commercial testing of Aspire: a yeast preparation for the biological control of postharvest decay of citrus. Biol. Control 12:97-101.

7. Droby, S., Vinokur, V., Weiss, B., Cohen, L., Daus, A., Goldschmidt, E. E., and Porat, R. 2002. Induction of resistance to Penicillium digitatum in grapefruit by the yeast biocontrol agent Candida oleophila. Phytopathology 92:393-399.

8. El-Ghaouth, A., Wilson, C. L., and Wisniewski, M. 1998. Ultrastructural and cytochemical aspects of the biological control of Botrytis cinerea by Candida saitoana in apple fruit. Phytopathology 88:282-291.

9. Fan, Q., and Tian, S. P. 2000. Postharvest biological control of Rhizopus rot of nectarine fruits by Pichia membranefaciens. Plant Dis. 84:1212-1216.

10. Fan, Q., and Tian, S. P. 2001. Postharvest biological control of grey mold and blue mold on apple by Cryptococcus albidus (Saito) Skinner. Postharvest Biol. Technol. 21:341350.

11. Janisiewicz, W. J. 1994. Enhancement of biocontrol of blue mold with the nutrient ana$\log$ 2-deoxy-D-glucose on apples and pears. Appl. Environ. Microbiol. 60:2671-2676.

12. Janisiewicz, W. J., and Korsten, L. 2002. Biological control of postharvest diseases of fruits. Annu. Rev. Phytopathol. 40:411-441.
13. Janisiewicz, W. J., Usall, J., and Bors, B. 1992 Nutritional enhancement of biocontrol of blue mold on apples. Phytopathology 82:1364-1370.

14. Ke, D., Gorsel, H. V., and Kader, A. A. 1990. Physiological and quality responses of 'Bartlett' pears to reduced $\mathrm{O}_{2}$ and enhanced $\mathrm{CO}_{2}$ levels and storage temperature. J. Am. Soc. Hortic. Sci. 115:435-439.

15. Lima, G., De-Curtis, F., Castoria, R., and DeCicco, V. 1998. Activity of the yeasts Cryptococcus laurentii and Rhodotorula glutinis against post-harvest rots on different fruits. Biocontrol Sci. Technol. 8:257-267.

16. Mclaughlin, R. J., Wilson, C. L., Droby, S., Ben-Arie, R., and Chalutz, E. 1992. Biological control of postharvest diseases of grape, peach, and apple with the yeasts Kloeckera apiculata and Candida guilliermondii. Plant Dis. 76:470-473.

17. Piano, S., Neyrotti, V., Migheli, Q., and Gullino, M. L. 1997. Biocontrol capability of Metschnikowia pulcherrima against Botrytis postharvest rot of apple. Postharvest Biol. Technol. 11:131-140.

18. Reuveni, M. 2000. Efficacy of trifloxystrobin (Flint), a new strobilurin fungicide, in controlling powdery mildews on apples, mango and nectarine, and rust on prune trees. Crop Prot. 19:335-341.

19. Roberts, R. G. 1990. Postharvest biological control of gray mold of apple by Cryptococcus laurentii. Phytopathology 80:526-530.

20. Rogiers, S. Y., and Knowles, N. R. 2000 Efficacy of low $\mathrm{O}_{2}$ and high $\mathrm{CO}_{2}$ atmospheres in maintaining the postharvest quality of saskatoon fruit (Amelanchier alnifolia Nutt.). Can. J. Plant Sci. 80:623-630.

21. Sams, C. E., and Conway, W. S. 1987. Additive effects of controlled-atmospheres storage and calcium chloride on decay, firmness retention, and ethylene production in apples. Plant Dis. 71:1003-1005.

22. Sitton, J. W., and Patterson, M. E. 1992. Effect of high-carbon dioxide and low-oxygen controlled atmospheres on postharvest decays of apples. Plant Dis. 76:992-995.

23. Smilanick, J. L., and Denis-Arrue, R. 1992. Control of green mold of lemons with Pseudomonas species. Plant Dis. 76:481-485.

24. Spadaro, D., Vola, R., Piano, S., and Gullino, M. L. 2002. Mechanisms of action and efficacy of four isolates of the yeast Metschnikowia pulcherrima active against postharvest pathogens on apples. Postharvest Biol. Technol. 24:123-134.

25. Spotts, R. A., Cervantes, L. A., and Facteau, T J. 2002. Integrated control of brown rot of sweet cherry fruit with a preharvest fungicide, a postharvest yeast, modified atmosphere packaging, and cold storage temperature. Postharvest Biol. Technol. 24:251-257.

26. Spotts, R. A., Cervantes, L. A., Facteau, T. J. and Chand-Goyal. 2002. Control of brown rot and blue mold of sweet cherry with preharvest iprodione, postharvest Cryptococcus infirmominiatus, and modified atmosphere packaging. Plant Dis. 82:1158-1160.

27. Sugar, D., and Spotts, R. A. 1999. Control of postharvest decay in pear by four laboratorygrown yeasts and two registered biocontrol products. Plant Dis. 83:155-158.

28. Tian, S. P. 2000. Manual of storage and manufacture of postharvest fruits and vegetables. Pages 120-123 in: Jujube. China Agriculture Press, Beijing, China.

29. Tian, S. P., Fan, Q., Xu, Y., and Jian, A. L. 2002. Effects of calcium on biocontrol activity of yeast antagonists against the postharvest fungal pathogen Rhizopus stolonifer. Plant Pathol. 51:352-358.

30. Tian, S. P., Fan, Q., Xu, Y., and Liu, H. B. 2002. Biocontrol efficacy of antagonist yeast to gray mold and blue mold on apples and pears in controlled atmospheres. Plant Dis. 
86:848-853.

31. Tian, S. P., Xu, Y., Jiang, A. L., and Gong, Q. Q. 2002. Physiological and quality responses of longan fruit to high $\mathrm{O}_{2}$ or high $\mathrm{CO}_{2}$ atmospheres in storage. Postharvest Biol. Technol. 24:335-340.

32. Wilson, C. L., and Chalutz, E. 1989. Posthar- vest biological control of Penicillium rots of citrus with antagonistic yeasts and bacteria. Sci. Hortic. 40:105-112.

33. Wilson, C. L., Wisniewski, M. E., Droby, S., and Chalutz, E. 1993. A selection strategy for microbial antagonists to control postharvest diseases of fruits and vegetables. Sci. Hortic.
53:183-189.

34. Wisniewski, M., Biles, C., Droby, S., Mclaughlin, R., Wilson, C., and Chalutz, E. 1991. Mode of action of the postharvest biocontrol yeast, Pichia guilliermondii. I: characterization of attachment to Botrytis cinerea. Physiol. Mol. Plant Pathol. 39:245-258. 